\title{
Effect of Temperature and Humidity on Serum Prostate Specific Antigen Levels in Asymptomatic Male Population
} Asemptomatik Erkek Popülasyonunda Sıcaklık ve Nemin Serum Prostat
Spesifik Antijen Düzeylerine Etkisi

\author{
Murat Tuğrul Eren1, Hakan Özveri2, Erdal Coşgun3 \\ 'Acıbadem University Vocational School of Health Services, Clinic of Urology, İstanbul, Turkey \\ 2 Acıbadem University Faculty of Medicine, Department of Urology, İstanbul, Turkey \\ 3Acibadem University Faculty of Medicine, Department of Biostatistics, İstanbul, Turkey
}

\section{What's known on the subject? and What does the study add?}

Prostate specific anigen (PSA) is still the only available proven laboratory test in clinician's hands for prostate cancer screening. However, many factors can cause a change in serum levels of PSA. This study is undertaken to determine the possible effect of climate parameters on individuals' PSA levels.

\section{ABSTRACT}

Objective

To determine the possible effect of climate parameters on prostate specific anigen (PSA) levels.

\section{Materials and Methods}

Among 2.150 males, 757 individuals participating in a general checkup service at our hospital group in the past one year were enrolled in this study. The mean age was 48.52 and all the individuals underwent PSA screening tests, abdominal ultrasonography examinations including prostatic evaluation, and urine examinations including microscopic evaluation. The data on climate parameters including daily minimum and maximum temperatures and their average values as well as daily moisture levels were obtained from the records of the Turkish State Meteorological Service, including 2 meteorological stations existed in the Anatolian part of İstanbul. First of all, the differences in climatic parameters between the two stations were analyzed. Then, the relationship of PSA levels with daily minimum, maximum and average temperatures along with moisture levels recorded by the two stations was statistically evaluated.

\section{Results}

The mean age of the subjects was $48.52(15-90)$ years and the percentage of individuals in age groups below 30, 31-40, 41-50 and over 50 were $5.2 \%, 23.2 \%, 31.8 \%$, and $39.8 \%$, respectively. The mean prostate volume measured by ultrasonography was $30.52 \mathrm{ml}$ which increased with age in compatible with the literature. The mean PSA value was $1.19 \mathrm{ng} / \mathrm{ml}$ in all age groups. PSA values were higher in older participants and in those with larger prostate volume. Only PSA and mean humidity levels were statistically different between the two stations $(p<0.05)$. When all parameters of temperature and humidity were grouped according to the

\section{ÖZ}

Amaç

Prostat spesifik antijenin (PSA) prostat kanseri tanısındaki hassasiyetini arttırmak amacıyla PSA düzeylerini etkileyebilecek faktörler literatürde araştırılmaktadır. Bu çalışmada, bireylerin PSA değerleri üzerinde sıcaklık ve nem gibi iklimsel parametrelerin olası etkisi araştırılmıştır.

\section{Gereç ve Yöntem}

Son 1 yıl içinde check-up yapılan 15-90 yaş aralığındaki 757 erkek retrospektif olarak değerlendirildi. Çalışma grubuna alınan bireylerin rektal muayene, abdominal ultrasonografi, idrar analizi ve serum PSA düzeyleri tespit edildi. İklimsel veriler (nem ve sıcaklık) Devlet Meteoroloji Kurumu kayıtlarından İstanbul Anadolu yakasındaki iki farklı istasyon (Kartal-Göztepe) baz alınarak elde edildi. İklimsel verilerden günlük minimum, maksimum ve ortalama sıcaklıklar ve yine günlük nem seviyeleri hastaların yaşadıkları lokasyona göre sorgulandı, yaşadığı lokasyona yakın olan meteoroloji istasyon verilerine göre düzenlendi ve iki gruba ayrılarak not edildi. İki istasyon arasındaki iklimsel parametreler analiz edildi ve karşılaştırıldı. Yine 2 istasyonun nem düzeyleri, günlük minimum, maksimum ve ortalama sıcaklıklar ve deneklerin PSA düzeyleri arasındaki ilişki karşılaştırıldı.

\section{Bulgular}

Çalışma grubunda ortalama yaş 48,52 (15-90) bulundu. Değerler $<30$ yaş, 31-40, 41-50 ve $>50$ yaş gruplarında hasta dağılımı sırasıyla $\% 5,2$, $\% 23,2, \% 31,8$ ve $\% 39,8$ idi. Ortalama ultrasonografik prostat büyüklüğü $30,52(10-185) \mathrm{ml}$ saptandı. Tüm yaş grupları için ortalama PSA 1,19 ng/ $\mathrm{ml}$ idi. İki farkıı lokasyonda sıcaklık parametreleri ortalama değerleri ile PSA seviyeleri arasında anlamlı fark saptanmadı $(p>0,05)$. Iki istasyon arasında PSA ve ortalama nem seviyeleri arasında ise istatistiksel anlamlı

\section{Correspondence}

Murat Tuğrul Eren MD, Acıbadem University Vocational School of Health Services, Clinic of Urology, İstanbul, Turkey

Phone: +90 2323244543 E-mail: doktormurateren@gmail.com Received: 01.07.2016 Accepted: 23.08.2016 


\section{ABSTRACT}

months and seasons, it was found that there was no statistically significant difference in PSA levels between the groups ( $p>0.05$ for all parameters). As for months and seasons, a statistically significant difference was observed between four seasons in all parameters of temperatures and humidity levels $(p<0.001)$, but this finding was not valid for alterations in PSA levels in these seasonal intervals. No significant relationship was found between the presence of white blood cells in urine and PSA levels and seasons seemed to have no statistically significant effect on the presence of leukocytes in urine ( $p>0.18$ and $p>0.5$, respectively).

\section{Conclusion}

Since any proven effect of climate on PSA will increase the sensitivity of PSA in diagnosing prostate cancer and may prevent the decision of an unnecessary biopsy, humidity with a possible influential effect on serum PSA level according to our study definitely needs clarification and confirmation. Therefore, future studies including large number of subjects with detailed data facilitating calculation of thermal sensation are needed to give clearer answers to this topic.

\section{Keywords}

Prostate specific antigen, prostate cancer, effect of climat, prostate specific antigen screning

\section{ÖZ}

fark saptandı $(p<0,05)$. Sıcaklık ve nem düzeylerinin tüm parametreleri ay ve mevsim olarak gruplandığında, deneklerin PSA düzeylerinde istatistiki olarak anlamlı fark olmadığı görüldü $(p<0,001)$. İdrarda lökosit varlığı ile PSA düzeyleri arasında bir ilişki görülmedi $(p>0,18)$. Ayrıca mevsimlerin idrarda lökosit varlığı üzerinde etkisi de gösterilemedi $(p>0,5)$.

\section{Sonuç}

PSA üzerinde farklı iklimsel parametrelerin etkisi prostat kanserinin teşhisinde PSA'nın hassasiyetini arttıracak bir bulgu olabilir. Araştırmamızda saptanan nem oranının PSA düzeylerine olası etkisi, gelecekte daha fazla sayıda denek içeren ve nemin sıcaklığa etkisi ile oluşan hissedilen sıcaklık (termal duyumsama) kavramının da ele alınacağı çalışmalarla daha net ortaya konulabilir.

\section{Anahtar Kelimeler}

Prostat spesifik antijen, prostat kanseri, iklim etkisi, prostat spesifik antijen taraması

\section{Introduction}

Prostate specific antigen (PSA) has been used for early detection of prostate cancer $(\mathrm{PCa})$ with no other competitor, yet proved to be superior $(1,2,3)$.

However, the fact that PSA is an organ-specific protein rather than a cancer-specific marker, causes this blood-test to possess some limitations, especially in the case of deciding to perform a related diagnostic prostate biopsy.

Therefore, contributory tests and evaluations have been used to increase the sensitivity of PSA based on the evidence that PSA levels can be affected by various other factors, such as prostatitis, urinary tract infection, and benign prostatic hyperplasia $(\mathrm{BPH})(4,5,6)$.

As for $\mathrm{PCa}$, in most cases when diagnosed, it grows slowly leading to a consequence that most men die due to causes other than PCa before the cancer becomes clinically evident and there is still no level 1 evidence that PSA screening reduces mortality due to $\mathrm{PCa}(7,8)$.

This is the fact that, indeed, the reasons for the ongoing debates about over-treatment of PCa originate from aggressive screening strategies. It is, then, the physician who should redress the balance between over and under diagnosis of PCa with the help of the patient informed well about the risks. This strategy refers to opportunistic screening rather than mass screening, hence, individualized risk-adapted strategy.

From the point of view of this opportunistic screening strategy, sometimes follow-up of low-risk patients with consecutive PSA tests before deciding a biopsy may become a reasonable solution relieving the concerns of the physician.

The question "does the climate affect the PSA level along with the other well-known factors like BPH, etc.?" has arisen for the very reason here, attempting to obtain an unaffected PSA at the right time and at right weather conditions of the individual's habitat.
City of İstanbul is located in a transitional climatic zone and, therefore, the Köppen-Geiger classification system defines the climate of this city as the mixture of three characteristic world climates: borderline Mediterranean climate, humid subtropical climate and oceanic climate (9).

This climatic variation generating especially fluctuations in temperature and humidity comes with dissimilarities in comparison with the uni-characteristic climates of many other world cities. High humidity is the other characteristics of this city reaching the level of $\% 80$ especially in the mornings.

In this research, we studied the effect of İstanbul's climate on PSA levels by using a population of male individuals performed a general check-up program that comes into service by our hospital group during a one year period.

\section{Materials and Methods}

Among 2.157 males, 757 individuals participating in a general checkup service at our hospital group during the year of 2012 were enrolled in this study. Serum PSA level was measured from the blood already taken for check-up program. Prostatic evaluation was performed using transabdominal ultrasonography. Urine samples were also obtained for urine analysis including microscopic evaluation. Ultrasonographic data was utilized to assess the size of the prostate. Microscopic urine examinations were evaluated for the presence of leukocytes for the reason that increased numbers may be related to the presence of infection. Study approval was obtained from the Acıbadem University Ethics Committee at the beginning of the study.

The data on climate parameters including daily minimum and maximum temperatures and their average values as well as daily humidity levels were obtained from the records of the Turkish State Meteorological Service, including 2 meteorological stations (Göztepe and Kartal stations) located in the Anatolian side of İstanbul. The aim 
of evaluating the records of the two stations was not to miss the temperature changes between different regions of this big city and to calculate the variances if existed. Another parameter calculated by using this data was the average previous ten days' values of each meteorological parameter, assuming that 2.8 days of PSA half-life should renew the production in 10 days. The units for temperatures were Celsius degree and percentage (\%) for humidity.

The region of the city where the participants spent their most of daily time were questioned and noted. Individuals declaring a region out of the coverage of the two stations were excluded from the study.

Having any lower urinary tract symptom suspicious for urinary infection was another exclusion criterion. The symptoms were supposed to interfere with the baseline PSA level of the participant. The other exclusion criterion was the presence of abnormal pathologic digital rectal examination.

First of all, the difference in climatic parameters between the two stations were analyzed. Then, the relationship of PSA levels with the daily minimum, maximum and average temperatures along with humidity levels recorded by the stations were statistically evaluated.

The presence of leukocytes in urine examination was presumed to be related with urinary infection including prostatitis. Therefore, a possible effect of leukocyturia on PSA levels and relationship of temperature and humidity with the number of leukocytes in urine examination were statistically investigated.

The data are expressed as mean, median, maximum and minimum values as descriptive statistics. The Mann Whitney-U test was used for comparing two groups and the Kruskal Wallis test was used for comparing more than two groups' measures. A two-sided $p$ value of less than 0.05 was considered statistically significant in all analyses. The statistical software SPSS 21.0 (IBM Company, USA) was used for the analysis.

\section{Results}

Among 2157 males, a total of 757 participants were enrolled in the study after the exclusion criteria was applied as written in the section materials and method. The mean age of the subjects was 48.52 years (range: 15-90) and the percentage of individuals in age groups of below $30,31-40,41-50$ and over 50 years was 5.2\%, 23.2\%, 31.8\%, and $39.8 \%$, respectively. The mean prostate volume measured by ultrasonography was $30.52 \mathrm{ml}$ which increased with age in compatible with the literature.

The mean PSA level was $1.19 \mathrm{ng} / \mathrm{ml}$ in all age groups. PSA values were higher in elderly participants and in those with larger prostatic sizes (Diagram 1, Table 1).

Table 1. Prostate spesific antigen values were higher at older participants and at participants with larger prostatic sizes

\begin{tabular}{|c|c|c|}
\hline & & PSA (ng/ml) \\
\hline & & Mean \\
\hline Age & $<30$ & 0.759 \\
\hline & $31-40$ & 0.756 \\
\hline & $41-50$ & 0.906 \\
\hline & $>50$ & 1.748 \\
\hline
\end{tabular}

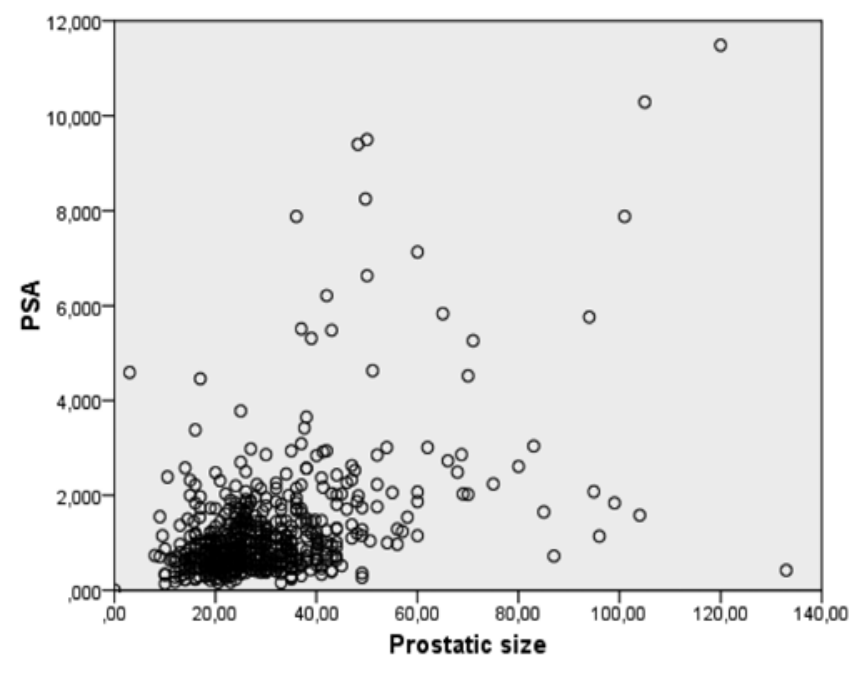

Diagram 1. Prostate spesific antigen values were higher at older participants and at participants with larger prostatic sizes

PSA: Prostate spesific antigen

\section{Statistical Analysis}

For statistical, analysis, the Mann Whitney-U test was used to compare the parameters between the two meteorological stations for the reason that quantitative data could not provide the provision of regular distribution from the parametric terms.

According to this analyze, only PSA and mean humidity levels were statistically different between the two stations $(p<0.05)$. The average PSA level was $1.201 \mathrm{ng} / \mathrm{ml}$ at Göztepe station while $1.118 \mathrm{ng} / \mathrm{ml}$ at Kartal station. The average humidity values from Göztepe and Kartal stations were 71.3 and 69.3, respectively. Other parameters including age, prostate volume, creatinine levels and temperature were not statistically different between two stations.

As for months and seasons, a statistically significant difference was observed in all parameters of temperatures and humidity levels between four seasons $(p<0.001)$ but this finding was not valid for alterations in PSA levels at these seasonal intervals (Table 2A, 2B). PSA levels and prostate volumes did not change during seasons and months correspondingly $(p>0.5)$.

Moreover, PSA levels in all participants did not change above and below the mean values of each weather parameter, including temperatures and humidity ( $p>0.05$ for all parameters) (Table 3 ).

As for presence of white blood cells (WBC) in microscopic urine examinations, this finding was more frequent in older age groups with larger prostates $(p<0.05)$ (Table 4).

However, the presence of WBC in urine did not affect PSA levels significantly and seasons seemed to have no statistically significant effect on the presence of leukocytes in urine $(p>0.18$ and $p>0.5$, respectively).

\section{Discussion}

A few number of researches with conflicting results have been performed regarding the investigation of climatic effects on PSA. The first study was from the French arm of the European Randomized Study of Screening for Prostate Cancer which revealed that total PSA 
Table 2A, 2B. As for months and seasons, a statistically

significant difference between four seasons at all parameters

of temperatures and humidity levels were observed $(p<0.001)$

but this finding was not valid for alterations of prostate specific antigen levels at these seasonal intervals

Table $2 \mathrm{~A}$

\begin{tabular}{|l|l|l|l|l|l|}
\hline \multicolumn{2}{|c|}{} & Frequency & Percent & $\begin{array}{l}\text { Valid } \\
\text { percent }\end{array}$ & $\begin{array}{l}\text { Cumulative } \\
\text { percent }\end{array}$ \\
\hline \multirow{4}{*}{ Valid } & Winter & 214 & 28.3 & 28.3 & 28.3 \\
\cline { 2 - 6 } & Spring & 195 & 25.8 & 25.8 & 54.0 \\
\cline { 2 - 6 } & Summer & 151 & 19.9 & 19.9 & 74.0 \\
\cline { 2 - 6 } & Autumn & 197 & 26.0 & 26.0 & 100.0 \\
\cline { 2 - 6 } & Total & 757 & 100.0 & 100.0 & \\
\hline
\end{tabular}

Table $2 B$.

\begin{tabular}{|c|c|c|c|c|}
\hline & Seasons & & & \\
\hline & Winter & Spring & Summer & Autumn \\
\hline & Mean & Mean & Mean & Mean \\
\hline Maximum temperaturesa & 9.1 & 17.6 & 30.9 & 23.0 \\
\hline $\begin{array}{l}\text { Average maximum } \\
\text { temperatures }{ }^{b}\end{array}$ & 9.6 & 16.9 & 30.3 & 23.6 \\
\hline Minimum temperaturesc & 3.0 & 9.1 & 21.2 & 15.2 \\
\hline $\begin{array}{l}\text { Average minimum } \\
\text { temperaturesd }\end{array}$ & 3.50 & 8.45 & 20.89 & 15.76 \\
\hline Humidity (\%) & 75.8 & 70.1 & 64.2 & 70.9 \\
\hline Average - humiditye & 75.5 & 70.0 & 65.0 & 71.3 \\
\hline Mean temperatures ${ }^{f}$ & 5.5 & 12.6 & 25.3 & 18.5 \\
\hline $\begin{array}{l}\text { Average - mean } \\
\text { temperaturesg }\end{array}$ & 5.91 & 12.08 & 25.04 & 18.92 \\
\hline Prostate volume $(\mathrm{ml})$ & 31.63 & 32.67 & 28.25 & 28.93 \\
\hline Creatinine $(\mathrm{mg} / \mathrm{dl})$ & 0.90 & 0.92 & 0.94 & 0.93 \\
\hline PSA (ng/ml) & 1.362 & 1.196 & 1.164 & 1.046 \\
\hline Age & 49 & 50 & 47 & 48 \\
\hline
\end{tabular}

levels were statistically significantly correlated with insolation, that is the monthly accrual in hours of sunshine during which the intensity was higher than 120 Watt.m-2 (10).

Then, another study found out that PSA levels were slightly higher during cold weather conditions. However, the small magnitude of alterations did not allow the authors to recommend to change the prostate biopsy indications according to climate conditions (11).

Seasonal variations in PSA levels were found to be apparent in another study performed by Connolly et al. (12) although age-adjusted PSA levels were deprived of the seasonal effect. The season of spring seemed to increase total PSA, which was not meanwhile correlated with daily, weekly or monthly hours of sunshine, rainfall or mean temperature in the study.

A study from Britain based on a huge number of data claimed that there was no pattern in PSA levels by time of year, air temperature or levels of sunlight in their cohort (13).
Table 3. Prostate specific antigen levels in all participants did not change above and below the mean values of each weather parameter, including temperatures and humidity ( $p>0.05$ for all parameters)

\begin{tabular}{|c|c|c|c|}
\hline & & \multicolumn{2}{|c|}{ PSA (ng/ml) } \\
\hline & & $\begin{array}{l}\text { Standard } \\
\text { deviation }\end{array}$ & Mean \\
\hline \multirow[t]{2}{*}{ Maximum temperaturesa } & Below mean & 1.149 & 1.158 \\
\hline & Above mean & 1.137 & 1.185 \\
\hline \multirow{2}{*}{$\begin{array}{l}\text { Average maximum } \\
\text { temperatures }{ }^{b}\end{array}$} & Below mean & 1.141 & 1.147 \\
\hline & Above mean & 1.143 & 1.193 \\
\hline \multirow[t]{2}{*}{ Minimum temperaturesc } & Below mean & 1.169 & 1.159 \\
\hline & Above mean & 1.118 & 1.182 \\
\hline \multirow{2}{*}{$\begin{array}{l}\text { Average minimum } \\
\text { temperaturesd }\end{array}$} & Below mean & 1.137 & 1.150 \\
\hline & Above mean & 1.146 & 1.191 \\
\hline \multirow{2}{*}{$\begin{array}{l}\text { Average minimum } \\
\text { temperatures }\end{array}$} & Below mean & 1.075 & 0.997 \\
\hline & Above mean & 1.203 & 1.309 \\
\hline \multirow[t]{2}{*}{ Average humiditye } & Below mean & 1.069 & 1.031 \\
\hline & Above mean & 1.205 & 1.278 \\
\hline \multirow[t]{2}{*}{ Mean temperatures ${ }^{f}$} & Below mean & 1.160 & 1.161 \\
\hline & Above mean & 1.125 & 1.181 \\
\hline \multirow{2}{*}{$\begin{array}{l}\text { Average mean } \\
\text { temperaturesg }\end{array}$} & Below mean & 1.144 & 1.161 \\
\hline & Above mean & 1.140 & 1.182 \\
\hline \multicolumn{4}{|c|}{$\begin{array}{l}\text { a, c, f: Daily maximum, minimum and average temperatures, }, b, e, d, g: \text { Average of } \\
\text { previous ten days' temperatures of maximum, minimum, average daily values and } \\
\text { humidity levels, PSA: Prostate specific antigen }\end{array}$} \\
\hline
\end{tabular}

The aim of our study was to evaluate basically the climatic effect on PSA levels at the cohort of İstanbul's male inhabitants. Our data at the participants' side included a wide range of age groups, prostate volume on ultrasonography, digital prostate examinations, and history of symptoms. The data of climate's side consisted of lowest, highest and mean daily temperatures with daily humidity levels.

The difference between our study and the previous ones was the development of study protocol on the basis of climatic data and participants' evaluation. The former was differently consisted of daily humidity levels and calculated average previous ten days' values of each parameter. Humidity is known to alter the wind-chill temperature and to have an effect on PSA. Ten days' average was calculated to strengthen real exposure of climate on participants while duration of 10 days was determined according to four times the PSA's half-life. However, neither the humidity levels nor the mean temperature of previous 10 days was shown consequently to have effect on the PSA significantly when the whole data was analyzed.

As for the latter difference, that is the participants' evaluation, these individuals had no significant symptoms and the reason for having these tests and examinations was just to be checked-up. We believe that this leads to a more refined population to be evaluated. The fact that every participant had ultrasonography, urine examination and physical evaluation also prompted refine determination about the relationship of PSA with climate. 
Table 4. As for presence of white blood cells in microscopic urine examinations, this finding was more frequent in older age groups with larger prostates $(p<0.05)$

\begin{tabular}{|c|c|c|c|c|c|c|c|c|c|c|}
\hline & \multicolumn{10}{|c|}{ WBCX in urine examination } \\
\hline & \multicolumn{5}{|c|}{ Exist (>4-5/hpf) } & \multicolumn{5}{|c|}{ Absent } \\
\hline & Mean & SD & Median & Minimum & Maximum & Mean & SD & Median & Minimum & Maximum \\
\hline Age & 48 & 12 & 47 & 15 & 86 & 51 & 13 & 51 & 20 & 90 \\
\hline Maximum temperaturesa & 19.2 & 9.1 & 19.5 & 1.3 & 38.6 & 19.5 & 9.1 & 19.5 & 0.0 & 38.6 \\
\hline $\begin{array}{l}\text { Average maximum } \\
\text { temperatures }{ }^{b}\end{array}$ & 19.2 & 8.8 & 19.5 & 1.2 & 35.4 & 19.3 & 8.6 & 20.0 & 3.9 & 35.2 \\
\hline Minimum temperaturesc & 11.3 & 7.6 & 12.0 & -3.7 & 25.8 & 11.7 & 7.6 & 12.0 & -37 & 25.8 \\
\hline $\begin{array}{l}\text { Average minimum } \\
\text { temperaturesd }^{d}\end{array}$ & 11.35 & 7.37 & 11.90 & -1.65 & 24.95 & 11.69 & 7.44 & 13.00 & -1.65 & 24.65 \\
\hline Humidity & 70.7 & 9.7 & 71.1 & 6.3 & 90.4 & 71.0 & 9.6 & 71.7 & 46.8 & 89.9 \\
\hline Average humiditye & 70.8 & 7.4 & 71.4 & 6.4 & 88.0 & 71.3 & 7.7 & 72.4 & 47.1 & 88.0 \\
\hline Mean temperatures ${ }^{f}$ & 14.5 & 8.2 & 15.3 & -2.4 & 29.4 & 14.9 & 8.2 & 15.0 & -2.5 & 29.4 \\
\hline $\begin{array}{l}\text { Average - mean } \\
\text { temperaturesg }\end{array}$ & 14.65 & 7.91 & 15.00 & -0.05 & 28.50 & 14.87 & 8.08 & 15.85 & 0.10 & 29.05 \\
\hline Prostate volume (ml) & 29.68 & 16.52 & 25.00 & 8.00 & 166.00 & 33.24 & 20.42 & 30.00 & 0.00 & 185.00 \\
\hline Creatinine & 0.92 & 0.15 & 0.91 & 0.51 & 1.73 & 0.92 & 0.15 & 0.90 & 0.60 & 0.78 \\
\hline PSA & 1.147 & 1.984 & 0.812 & 0.003 & 41.520 & 1.362 & 1.484 & 0.900 & 0.003 & 11.490 \\
\hline
\end{tabular}

The only statistically significant difference in our study was between humidity and PSA levels when the two meteorological stations were taken into account. This is the first evidence that humidity may affect PSA. This may be explained by the concept of relative temperature and thermal sensation which is defined as how hot the weather feels to the average person, because humidity is well-known to be a strong component when to evaluate thermal sensation along with the other factors like metabolic rate, clothing, air temperature, mean radiant temperature and air velocity (14). Therefore, when all of these factors are taken into account along with humidity in the future studies, PSA-climate relation may be shown on a stronger scientifically proven basis.

The incidental finding of leukocytes in urine seemed to have no effect on PSA levels. This finding, along with the result that seasonal temperature changes and humidity did not correlate with leukocyturia, may be an evidence that raises doubts about anticipating cold exposure-urinary infection-leukocyturia-rising PSA engagement at all times unless the patient has urinary symptoms. The individuals in our study group had no urinary symptoms at all.

\section{Conclusion}

This research originating from our small number of daily clinical observations which brought us to a hypothesis that İstanbul's mixed transitional climate may affect PSA levels did not put an end-point to debates about PSA-climate relationship even if it proves that the temperature parameters are uninfluential in PSA levels except humidity. On the contrary, from evolving out of humidity-PSA relationship, it leads to a conclusion that thermal sensation of individuals must be evaluated to reach to more precise results in future studies.
Since any proven effect of climate on PSA will increase the sensitivity of PSA in diagnosing PCa and may prevent the decision of an unnecessary biopsy, humidity with a possible influential effect on serum PSA level according to our study definitely needs clarification and confirmation. Therefore, future studies including large number of subjects with detailed data facilitating calculation of thermal sensation are needed to give clearer answers to this topic.

\section{Ethics}

Informed Consent: A retrospective study.

Peer-review: Internal peer-reviewed.

\section{Authorship Contributions}

Concept: Murat Tuğrul Eren, Hakan Özveri, Design: Murat Tuğrul Eren, Hakan Özveri, Data Collection or Processing: Murat Tuğrul Eren, Hakan Özveri, Erdal Coşgun, Analysis or Interpretation: Murat Tuğrul Eren, Hakan Özveri, Erdal Coşgun, Literature Research: Murat Tuğrul Eren, Hakan Özveri, Writing: Murat Tuğrul Eren, Hakan Özveri.

Conflict of Interest: No conflict of interest was declared by the authors. Financial Disclosure: The authors declared that this study has received no financial support.

\section{References}

1. Catalona WJ, Richie JP, Ahmann FR, Hudson MA, Scardino PT, Flanigan $R C$, deKernion JB, Ratliff TL, Kavoussi LR, Dalkin BL. Comparison of digital rectal examination and serum prostate specific antigen in the early detection of prostate cancer: results of a multicenter clinical trial of 6,630 men. J Urol 1994;151:1283-1290.

2. Catalona WJ, Loeb S. The PSA era is not over for prostate cancer. Eur Urol 2005;48:541-545. 
3. Thompson IM. PSA: a biomarker for disease. A biomarker for clinical trials. How useful is it?" J Nutr 2006;136:2704.

4. Andriole GL Jr. PSA screening and prostate cancer risk reduction. Urol Oncol 2012;30:936-937.

5. Barry MJ. Evaluation of symptoms and quality of life in men with benign prostatic hyperplasia. Urology 2001;58(Suppl 1):25-32.

6. Schröder FH. PSA screening-a review of recent studies. Eur J Cancer 2009;45(Suppl 1):402-404.

7. Hoffman RM, Fletcher RH, O'Leary MP, Rind DM. Screening for prostate cancer. In: UpToDate [Internet]. Waltham (MA): UpToDate; 1992-2013. Available from: www.uptodate.com

8. Ilic D, Neuberger MM, Djulbegovic M, Dahm P. Screening for prostate cancer. Cochrane Database Syst Rev 2013:CD004720.

9. Kottek M, Grieser J, Beck C, Rudolf B, Rubel F. World Map of the KöppenGeiger climate classification updated. Meteorol 2006;15:259-263.
10. Salama G, Noirot O, Bataille V, Malavaud S, Rebillard X, Villers A, Malavaud $B$; French arm of the ERSPC study. Seasonality of serum prostate-specific antigen levels: a population-based study. Eur Urol 2007;52:708-714.

11. Luján Galán M, Pascual Mateo $C$, Rodríguez Garcia N, Garcia Mediero JM, Pascual Durán T, Paez Borda A, Berenguer Sánchez A. Impact of the weather on the serum levels of prostatic specific antigen (PSA). Arch Esp Urol 2006;59:247-252.

12. Connolly D, van Leeuwen PJ, Bailie J, Black A, Murray $\sqcup$, Keane PF, Gavin A. Daily, monthly and seasonal variation in PSA levels and the association with weather parameters. Prostate Cancer Prostatic Dis 2011;14:58-62.

13. Down L, Metcalfe C, Martin RM, Neal DE, Hamdy FC, Donovan JL, Lane JA. Seasonal variation in prostate-specific antigen levels: a large crosssectional study of men in the UK. BJU Int 2011;108:1409-1414.

14. d'Ambrosio Alfano FR, Palella BI, Riccio G. Thermal environment assessment reliability using temperature-humidity indices. Ind Health 2011:49:95-106. 